\title{
Taking Women Seriously MaKes Us SMARTER ABOUT THE U.S. WAR IN IRAQ
}

\author{
Cynthia Enloe \\ Clark University \\ Prepared by Elizabeth Miklya Legerski \\ University of Kansas
}

It's great to be here. It's my first visit to KU; my first visit to Lawrence. Where have I been all these years? [Audience laughter] When you are a visiting person and you're picked up at the airport, you are lucky if you miss the exit; then you get a longer ride and that means that you learn more. So on the ride in from the airport I got a quick seminar on Kansas politics and Johnson County politics. Then over lunch I got some University of Kansas politics versus Kansas State University politics. [Audience laughter] From the top of the sociology building I got to see the football stadium. I got to see the chapel built by German prisoners of war. Not to mention lunch in the bank, which is just like a real bank; you give in the money and you don't get it back. [Audience laughter] It's really a delight to be here at the University of Kansas; my visit is long overdue. I really feel as though I am very fortunate to have been asked by the sociology department to speak. I am a very proud political scientist, but I am delighted to be seen as of some relevance to the good, smart folks in sociology.

When Joey Sprague and I started our email conversation about what you all might find interesting - and of course this was back last fall, these things are a long time in the making - we didn't really know what would be happening in Iraq now. But I had a sense that we should be talking about it, and that maybe we should try and ask the question - not as if I have all the answers - but ask a very practical, down-to-earth question, and that question was 
what do we miss if we don't take women's lives seriously in the war in Iraq? What do we miss? It's the kind of question I think we should all ask anytime a professor introduces a new concept or says you have to know this. Usually what goes on in your head is, why? What will having a concept of say, social inequality, do for me? Why is that useful? What will I see that I otherwise can't see? If I have a new concept why does it make me smarter? That is, why does my eyesight get better? Underneath every research question is an argument that if you really pursue you'll actually be - we will actually be - marter about the world. And when I say smarter what I mean is I will be more realistic. I won't be naïve. I won't be simplistic. To be smarter means that I will be more subtle; I'll be more nuanced — or at least I have the potential to be. Sometimes we don't live up to the potential, but there's at least the possibility that my view of the world will be more subtle, more nuanced. It also means that I'll have a better sense of what causes what. As somebody in the social sciences, one of things that I constantly ask is what causes what? And I'm always afraid that I've missed it. I'm always afraid that my answer to what causes what is naïve, is too simplistic, too parochial, too American, too middle-class, too white, or just plain uneducated.

So when I began thinking with Joey via email on what might be a good question for us to pursue together today, I thought let's take one that is very much on our minds; and that question is, how do you understand, how do each of us make sense of, the war in Iraq? I'd like to introduce today four women as a way of making sense of the war in Iraq. [Pointing to an audience member] You're trying not to catch my eye. It's just like the way I was in high school Latin. [Audience laughter] I thought if I didn't look at the teacher he would never call on me. But I found you. What's your name?

Ivory.

Ivory, you don't have to do anything except stand up. Ok, stand up. [Audience laughter] This is not a test, okay? Ivory is a woman; an American woman outside of San Francisco named Kim Gorskiwho is a real woman. [To audience member] You are now Kim. Kim, you are married to an American guy named Mike, and Mike and you are now living continents apart because Mike is in the 
National Guard and he has been sent to Iraq. And this is what we found out about Kim Gorski. Now before I go on, notice what I'm doing. I'm saying, be interested in Kim to help make sense of the U.S. war in Iraq. Be interested not in Mike-you can be interested in him, but don't be mainly interested in him-be mainly interested in Kim. That is, be interested in somebody that the Pentagon thinks of as a military wife. Then make sense of foreign policy, and particularly military policy, by taking seriously what's going on in Kim's head, what she's having to deal with in her life, and what the U.S. government expects of her. [To audience member] By the way, the U.S. government counts on you for a lot, and if we pay attention to you we'll be a lot smarter about what it takes for any government to try and wage a war.

Here's what Kim Gorski is going through. We know this because she was interviewed in the New York Times ${ }^{1}$. That is, a good reporter actually thought Kim Gorski would be interesting as a way to report on the war in Iraq. We know that Kim is 30. She and her husband both identify as white. We know that they haven't been married very long. They don't have any kids yet. Mike had been in the military previously, but he got out of the military and decided-[To audience member] with your agreement I think, it's that kind of marriage where you actually talk about things - that he wanted to continue to do something patriotic. Now these are his terms; he is linking masculinity and adulthood to something called patriotism. So when he got out of the active duty military he decided that he wanted to sign up for the National Guard. Why? You have to think about what it's like to sign up for the National Guard if you live in the San Francisco area. What do you think you're going to be doing when you sign up for the National Guard there? Earthquake relief, and that is what he thought he would be doing. He thought I am going to sign up with the National Guard and if the next big earthquake happens - and everybody is predicting its going to happen-I'll be of use; I can actually make a social contribution be being in the California National Guard. But of course in the National Guard - and a lot of you know this because you probably have friends or relatives who are in the National Guard or in the Reserves-you can go get a regular civilian job at the same 
time. So he got a job with a bank and was being trained to be an assistant bank manager. He is just beginning his career. He's also about 30 years old. [To audience member] And you, Kim, were going to go for your real estate license.

So you've been studying for your real estate license and Mike is trying to make his career at a bank and along comes the invasion, first of Afghanistan in October of 2001, and then the build up and invasion of Iraq in March of 2003. This puts an enormous strain on the U.S. military. Now we have to talk about what Rumsfeld was actually thinking about because it's very important. Donald Rumsfeld, as Secretary of Defense, had a whole theory about the way he was going to remake - he would say modernize - the American military by making every U.S. military operation doable with fewer personnel - that's one of the main Rumsfeld arguments. And if you think that the Defense Department is one big happy family, they are not. Most of the joint chiefs-of-staff were, in fact, very unhappy with Rumsfeld. There was a real parting of ways; Rumsfeld actually got rid of - or forced into early retirement-a number of senior generals. If you watched the Democratic National Convention - for whatever reason you watched it - one of the things you might have noticed on the night they called national security night was that they had a number of senior generals, all very recently retired and wearing civilian clothes, who came out for Kerry. And if you've been watching the news you would know exactly who those generals were; those were generals who disagreed with Rumsfeld and the new Rumsfeld Doctrine that the U.S. military can carry on multiple operations simultaneously with an active duty force smaller than ever.

Connect the dots here - that is going to affect Kim Gorski's relationship to Mike Gorski because what has happened is that the National Guard and the Reserves have had to be called up in record numbers in order to carry out an operation that turned out not to be able to be successful with such a small force. So Mike is called up and Kim has to decide what she is going to do. That is, her marriage is now going to be deeply affected by the fact that Mike is called up for active duty — and its not earthquake duty — but to be sent to Iraq as a military policeman, which is one of the main duties 
of the Reserves and the National Guard. We learned this at Abu Ghraib; the main military police unit in Abu Ghraib was a Reserves unit. That's not by chance. And so Mike is sent to Iraq and it turns out that he's going to be there for over a year. That's not your two weeks in the summer. But Mike is lucky. We learn from the interview with Kim Gorski, his wife, that he works for a bank that is going to do more than the law requires; the U.S. federal law requires that anybody who is called up to active duty out of the Reserves or the National Guard must have their job held for them at their current employment — not with any pay, but at least the job has to be kept. Think about families now. There is a reason that a lot of military families are on food stamps. Kim's husband, Mike, was lucky enough to be working for a bank that had their own policies on military service and they decided to continue to pay Mike's salary during the time that he is called to duty - not just to save his job.

That was tense, but there was so much more that Kim was now expected to do. She doesn't have kids; she didn't all-of-asudden become a single parent like most Reserve and National Guard wives are - that's what happens in the military, you become an instant single mother. They didn't have any children, but what if you got a call from the Pentagon asking you, because Mike is an officer in his unit, asking Kim to please take responsibility for the morale of all the wives, and fiancés, and girlfriends of all the men in his unit. Remember, Kim is not in the military. Kim is not getting a military salary. Kim does not have a military rank, but she is called upon. This is actually standard procedure in the last fifteen years of the United States military; it has become much more standardized since Gulf War I. Family politics - which I know you know a lot about, those of you who have taken sociology - is deeply affected by the U.S. military's policy. In fact, the Defense Department of the United States hires more sociologists to study wives than any other military in the world. Sociologists are thought to be very useful to the U.S. military; [Audience laughter] and at a time when the social sciences are being under-funded for research, it is very appealing to may social scientists to get a Defense Department contract. I've talked to people in Britain, for instance, and 
they say, we don't hire anywhere near as many social scientists as the Americans do. This really began in World War II when the U.S. military figured out you've got to be able to make the wives work for you if you're going to be able to enhance morale. Remember morale? If you're on any sports team, your coaches always talk about morale; they strategize about morale. Well, militaries always think about morale and they think about who could damage morale.

So let's say Kim's there, on Baghdad-by-the-sea, out in San Francisco. She's a little resentful. The first two months were okay but now she's had to drop her real estate license courses. This isn't what she planned for. Also, she's not sure now when are they going to start a family. She's not sure what Mike's going to be like when he gets back-being in a combat zone is not necessarily good for one's stress levels. This is not true of Kim, so let's say somebody else, another woman in Kim's unit — see the slippage? This is the way Kim is encouraged to think about it. There is no other woman is in Kim's unit, but Kim begins to hear that one of the other women in her unit is beginning to think that maybe they've got to get divorced. After six months of separation and all this stress, the other woman, Mary, and her husband John, think maybe it isn't working out so well. What do you think the Defense Department wants Kim to say to Mary? You're in the Defense Department now; all you care is about the effective waging of an overseas war by the U.S. military - that's your basic criterion for judging anything. What are you afraid that Mary is going to do? Divorce her husband. What are you afraid she is going to write on the internet or send in a letter? Dear John. [Audience laughter] How many of you remember the song? Dear John, oh how I hate to write. Dear John, I must let you know tonight. Oh my love for you is gone. That's a Korean War country western song, and that is the fear of every military commander; that women will lower the morale of the fighting men by not staying loyal to them when they are sent overseas. And so Kim is supposed to make sure that Mary does not file divorce papers, that Mary does not write a Dear John letter. She is encouraged to get on the phone and to answer, even if she gets calls at two o'clock in the morning. She says to the New 
York Times reporter, I'm glad to do it. I'm glad to do this work. I've got women in Mike's unit, women who are fiancés or wives, and they are so stressed out. They can't make the bills. They're having trouble with childcare. How can they hold on to their job when they are now instant single mothers? And I'm just Kim. I'm just trying to be of help. But you know, I'm not a guidance counselor. I'm not a social worker. I have no resources to hand out.

Now here is the first lesson you learn, or that has taken me a long time to learn. But first, I have to tell you that when Joane Nagle mentioned the book "Does Khaki Become You" in her introduction today, it reminded me that back in 1983 the chapter that made me the most nervous to write was the chapter that I called "Military Wives." Remember, I'm a political scientist; we're kind of nervous types because we have such a narrow definition of politics compared to you sociologists who know its everywhere. I thought then, oh my gosh, all my political science senior professors will think I'm a sociologist. [Audience laughter] That's a fear, I have to tell you, that they will think I'm not serious. [Audience laughter] But every discipline is like that. Every discipline is always kind of guarding the boundaries - except for sociologists at KU who don't do that. [Audience laughter] It really was a stretch for me to imagine that the only way that I could genuinely make sense of militaries around the world, was to take seriously the Kim Gorski's; that I had to actually start being interested in military families. The reason I had to be interested in military families is because the ministries of defense-what the Americans call the Department of Defense - around the world thought about wives all the time. If I was going to be realistic - if I wasn't going to be naïve and simplistic about how militaries run their affairs, how they engage in war waging - then I am going to have to be interested in everybody that every defense ministry expert is going to be interested in. I had to start thinking about being different, and try to think about it from the lives of the women married to soldiers.

Some of you probably have relatives who are military wives, or have been military wives for a short time. If you do, be sure and go interview them about that time in their life, but assume that what you are doing is an interview about world affairs. You are 
doing interviews about the dynamics of families, but the dynamics of families are part and parcel of world affairs. Insofar as any military cannot control the actions and the emotions of women married to soldiers, they think they cannot actually carry on effective foreign policy. Now that is a radical thing to argue, but I actually have come to believe it's true. If you start taking seriously the ideas and the motivations and the mixed feelings of women married to soldiers, you will not find that they all have the same opinion. A lot of them are like Kim, who, when she interviewed with the New York Times said she was happy to play that role. It was stressful; she had to sacrifice her own career, at least temporarily. She wasn't sure what was going to happen to her marriage, but she was glad to do it. Militaries around the world-we're talking about Indonesia, we're talking about Russia, we're talking about Kenya, we're talking about Chile — and the governments behind those militaries, encourage women to see themselves as doing patriotic duty through their roles as wives.

Many of you know - especially if you've taken any gender in society courses, or women's studies courses, or women in politics courses - that around the world one of the most deep seated, and common assumptions across very different cultures is that women's place is in the private sphere; that women are most "naturally" suited to the private sphere. Whenever you see the word naturally put neon lit quotes around it. [Audience laughter] When anybody says something is natural they are actually saying, please don't question that, please don't look too closely at that, you don' have to be curious about that, please don't do your honors thesis on that. [Audience laughter] There has been this widespread assumption that women's natural inclination is to be a mother and a wife. And in fact, that's one of the main arguments for women not getting the vote. When did women in Kansas get to vote? 1912? When did Kansas come into the Union? 1861? You'll notice the gap theremind you the people in Massachusetts couldn't do anything. [Audience laughter] In the creation of a political community it was presumed that it was natural not to include women as public actors. That's based on this notion that women's lives are most naturally conducted in the private sphere; that's where they're most 
rewarded, that's where they're most fulfilled, that's where they're most skilled, that's where they're most valuable. They believed that women having a public voice was unnatural; not to mention dangerous and at least superficial, because a father, or a brother, or a husband will vote in her interest. Of any society you should study, study how persuasive it was for the anti-suffrage movement to argue that women do not need, do not deserve, and cannot be trusted with the vote. Anti-suffragists were persuasive for decades, for generations; they are not just coots. But watch how this serves the U.S. military and the war in Iraq, even though women have the vote here.

If you can encourage a military wife or you can encourage a woman married to a soldier to identify herself mainly as a military wife, and to imagine that her greatest contribution to the country's security is mediated through her role as a wife, then women's value as citizens and as patriots is embedded in their roles as mothers of soldiers and wives of soldiers, not as spokespeople on foreign policy. That's not true of Mike. See the difference between Mike's role and Kim's? Mike's main contribution to American national security is as himself, as a soldier, not as a husband, not as a father, although he's identified as that, or will in the future. No, no, he's not mainly a husband; he's mainly Mike, the public man. Kim gets to be a public person mainly through him. This is how she is viewed from Washington and this is how she is viewed from many of her family and friends who think this is the main way she is going to be contributing to American security. This is the way she's going to earn her 'ribbons,' if you will, as a patriot, as a good citizen; through being a wife or the good mother of a soldier.

Let's take somebody really different now. Okay Joey, stand up [Audience laughter]. I'm not going to repeat what she just said. No, it's going to be a little different. Joey is also an American woman who is getting a lot of her sense of value from the military but she, unlike Kim, has actually joined the active duty U.S. military. Your name is anonymous because you don't want to give your name in public. You're about 26 and you're an African-American woman. You've joined the U.S. military as a way to get out of your small town, to see the world, to do something that none of 
your sisters or mothers or aunts have never done, to sort of break new ground, to actually feel like a public person, and to feel like contributing to the nation - one of the things that most militaries encourage us to think is that a first-class citizen is first of all a soldier, not an emergency room nurse, a childcare center worker, or a medic. Anyway, you're deployed in a mainly male unit, like most women in the U.S. military are; of the active duty military, women are about 15 percent. Women make up about 24 percent of the Reserves, but of all the troops that have been sent to Iraq and Afghanistan, women are only about ten percent. You are really pleased that you're going to be deployed to one of the main "theatres of action" - this is how militaries talk. So you are a mechanic and you have been deployed with your unit to Kuwait, which is one of the main staging grounds used by the U.S. government for its operations in Iraq. Negotiations with the Kuwaiti government went on long before the Bush Administration was willing to talk about engaging; we now know that started in about 2002. These diplomatic negotiations take a lot of time.

So you're stationed in Kuwait. Here's the reason that this woman only wants to be know to all of us as anonymous. She's now come home, she's done her duty, she's rotated out, and she's now a civilian. It is as a civilian that she decided she could talk. She's from Denver Colorado, and she went to the Denver Post, who wrote this story, after a counselor who she'd been talking with urged her to tell her story. She was raped in Kuwait by a fellow American male soldier. It was a horrific ordeal. We actually have these stories. It was a horrific ordeal, a lot of you know this, but she got the courage to go to her commanding officer, her superior, to say what had happened later that morning. She had been out at night at a latrine when was attacked. Her commanding officer did not send her to a hospital; the commanding officer had no access, that is, he didn't think that part of having a command resource is to have rape kits, so no rape kit was collected. His advice to anonymous was to get over it; we have a war to fight. That is, we have more important things to do; you'll be okay, you're alive, so deal with it. Now what we know is that this is not the only incident, and we know this because of the Denver Post and also 
because of an independent organization based in Connecticut that supports the rights of women in the U.S. military called the Miles Foundation. The word put out from the Denver Post to the Miles Foundation is that we've been hearing these stories from other people. The total so far is up to 68 American women who have been raped by American male soldiers, while in their own units, while on duty in Kuwait, Iraq, and Afghanistan. We have no idea how many women are not telling; it takes a lot of guts to tell about sexual assault.

So what does this tell us? This tells us that in every military there are things that are silenced. In every military there are politics of sexuality. Sometimes the politics of sexuality are about women working in prostitution around U.S. military bases. What is the nearest military base to here? Fort Riley? Oh, there's been a series of articles about Fort Riley in the New York Times. Its women who live and work in Fort Riley; its women who live and work around the U.S. bases in Dubai, in South Korea, in Guam, in Hawaii, in Kazakhstan, in the Philippines. And what we now know is that we don't know what the full politics of sexualized power are inside of the U.S. military - or any other military for that matter. But once you begin to realize you don't know about something, it makes you cautionary about thinking that you do know what a military is. Some of the first stories that came out about sexual abuse, all of them by American male soldiers, although not all of them within the women's own unit, came out during this thing called "peace time." Militaries in peace time are at least as interesting as militaries during war time. But during war time it allows commanders, who are uncomfortable with the thought that there may be sexual abuse in their own ranks, to imagine for the sake of war waging priorities - which after all is more important than any other priority - that a women should get over it; that it's okay not to have a rape kit.

Let's switch places again. Stand up, what's your name? Julie.

Julie is an Iraqi woman named Nimo. We know about Nimo because she has also been interviewed by a woman reporter of the New York Times ${ }^{2}$. This is one of the reasons why it's so 
important that both women and men, including the university's own newspaper, be journalistic staff; its not just that female journalists can get access to women locally who will talk to them, but also they actually imagine that they might be interesting in the first place. This is not automatic. You can train any woman in any profession to try and deny that she is a woman. A lot of professions-law, banking, journalism, even political science and sociology-oftentimes have cultures that encourage women who join those professions to do everything they can to deny that they are women. You want me to go and visit and make a story out of Nimo? I want to be on the front lines! That's how I'm going to get my promotion with the New York Times. Don't go and tell me to go talk to local women. What do you think I am, on the style page? This is real serious sexism inside journalism. But this reporter actually did think that the way to make sense of what's going on in Iraq is to take seriously some women who are not in power, who do not wield violence, and who are not in any high level cabinet position.

Here's who Nimo is; Nimo is in her late 30s and she lives in Baghdad. She runs a beauty parlor, which really is just a part of the living room of her very small house which is on a back street in one of the crowded neighborhoods of Baghdad. So Nimo is a selfmade business woman in a very modest way. The current figures are that 60 percent of all Iraqi adults are unemployed. Sixty percent is the combined figure for women and men; the percentages of women are higher, closer to 70 percent. And being employed doesn't mean employed for a livable wage. But Nimo has actually been able to sustain her little beauty parlor through the Saddam Hussein years and through the war since March 2002. [To audience member] You give perms and you do facials and nails. Women locally feel this is a safe place to come. Now that makes a big difference, because one of the things that we are learning about the Iraq war is how many women, even in Baghdad, feel insecure. And insecurity for women means you do not leave the house. If you were a geographer one of the things you would be interested in is women's mobility. If you take any place that isn't a war zone and look at women's physical mobility, it will never be as wide in its 
geographic space as men's mobility. Mobility is how far you can go from the place that other people think is your home; that distance is very gendered. Then take a war - any war zone in any place, take the Congo, take Sri Lanka, take Chechnya-and one of the first things that happens to women and girls' mobility is it shrinks. Why? Because the idea of insecurity for women is so closely attached to feminized respectability. Now I know that in a lot of your sociology courses you probably talk about femininity, you probably also talk about social respectability; respectability is just like beauty, it is in the eye of the beholder. That is, other people get to say whether you are respectable. In zones of war, in insecure times, parents, fiancés, uncles, aunts, are very concerned about young women's respectability; they will not be subject to sexual assault or to other kinds of experiences that will damage their status as a respectable woman. In most societies women's main currency - their conceptual money in the bank-is their status of family respectability. This is just like Jane Austen, but it's still alive and well today. A woman who is charged with having lost her feminine respectability looses a lot, more so than a man does.

Nimo provides a place that women can come to. It's a women only space, it's in a neighborhood, its doing non-political, non-threatening things, like having your hair meshed. One thing we learn about Nimo's beauty salon is that both women who have adopted the head scarf and women who don't wear the head scarf come; women who are older and women who are younger come. This is a very imaginative piece of journalism; most journalists don't ask Nimo what she thinks about running a beauty salon in a war zone. But this journalist sat there, and with a translator listened to these conversations as a way to cover Iraqi politics. Always go to beauty parlors because oftentimes the conversations are highly political. But most of the women who are carrying on the conversations there, and certainly Nimo would say, I'm not political, we aren't involved in politics. Now that does two things: one, this we're not political talk is freeing. It allows a lot of women to discuss all kinds of things that if you and I listened to we'd say, they're talking about national security, they're talking about the occupation, they're talking about who's got power and who doesn't, they're 
talking about whether the new Iraqi police force formed by the U.S. occupation forces is effective enough. Sounds pretty political to me. But women in many societies think they can't imagine talking politics, when in fact, they can talk politics. That's the good news. The bad news about their freedom to talk politics, but to deny that they are talking politics, is that nobody else thinks they are talking politics either. Nobody else thinks, oh, if you want to know what's going on in Iraqi political life, go spend some time in Nimo's beauty salon. No, no, they think you have to go into the green zone; that you have to go talk to the U.S. Ambassador or the new Prime Minister of Iraq. They think that's political talk. The fact that no one thinks women talk politics is the very thing that frees up women at Nimo's beauty salon to talk politics, especially about the rates of women's kidnapping since the beginning of the occupation, which has gone sky high, partly because the police pay no attention because they say it's not a really urgent issue. Women being kidnapped, women being abducted by other Iraqis, either for sexual abuse or for ransom, that, say the police, is not really about national reconstruction; that is just about the silliness of a woman. What does she think going out on the street anyway - especially without a scarf?

And that brings me to one final woman. [To male audience member] Stand up. [Audience laughter] That's you — absolutely, come on! We're acting here. You're nice and tall, so that's why it has to be you. You're a woman named Kitab Jaleel. And you are a really sophisticated Iraqi woman. You are 46 and you've worked for the state electrical corporation; you're an engineer. But you lost your job under the Saddam Hussein regime because you refused to join the Ba'ath Party, and having refused to join the Ba'ath Party you got fired. But you stayed in Iraq, and you've become more political. In fact, having refused to join the Ba'ath Party and then suffering the consequence of it is one of the things that made you political. This is now the third war for the Iraqi people in the last 25 years. Americans have a terrible habit of imaging the war that Americans fight in a country is the only war that that country has ever fought. For example, we talk about Vietnam as if a country is our war. Don't ever say Vietnam when what you mean is the 
U.S. war in Vietnam; that's not the same as Vietnam. The Vietnamese fought three wars before they fought the war with the United States. The Iraqis have also gone through an eight year war between Iraq and Iran; a devastating war. And then they went through Saddam Hussein launching the occupation of Kuwait and therefore the U.S. and allied response - it wasn't actually an allied response. So this is Jaleel's third war. One of the things that Jaleel has said to reporters is that with every war ideas about what is proper for women changes, and usually for the worse.

In the U.S. experience we think of war as being liberating for women. Just think of the example of World War II and Rosie the Riveter. Who has the classic Rosie the Riveter poster? Look around everybody, look around. Rosie the Riveter? Me too. I even found in Chicago last month a Rosie the Riveter action doll. [To audience member] Do you have one too? She has her little drill and a lunch box. We still wear our Rosie the Riveter T-shirts and are happy with our action dolls and everything, but watch how the myth behind Rosie the Riveter works. Rosie the Riveter is so popular in the United States mentality because it assumes that World War II was good for lots of American women. World War II sent the guys off to Europe and the Pacific and it opened up for the first time good-paying industrial jobs that guys always had. Industrial jobs are always better paid than home care jobs or agriculture jobs, and the war opened up those good-paying industrial jobs to women. Rosie the Riveter is a woman who went from either getting no pay or low pay to getting a welder's pay. One of the reasons that those t-shirts sell-the Rosie the Riveter, "we can do it" [makes a flexed arm gesture], she had bigger muscles than I do-is the idea that World War II was good for women's liberation in the United States. But you've got to really watch it because that is not the experience of most women in most countries in the world. It may not even be the experience of most American women in World War II, but it is certainly not the experience of Iraqi women.

Jaleel is much more educated than Nimo, but Nimo has an occupation; Jaleel is now unemployed. But what Jaleel has seen, and she's older than Nimo so she has longer experience, is that 
with every single war - the Iran-Iraq war, which was devastating, the Gulf War I, thanks to Saddam Hussein's bizarre notion that he could occupy another country without any retribution, and now this occupation and instability-has caused many men who run the political parties and who run the intellectual establishment to think that our society is in such disarray because of losing wars and being occupied by foreigners that the one thing we can do to prove our integrity and dignity as a nation is to ensure that our women are respectable. So the pressure on Jaleel to wear a head scarf, which she has never worn before, has increased dramatically in the last three years. People who never expected her as a trained engineer at the electrical state corporation to wear to a head scarf are now pressuring her to wear it. But Jaleel is holding out because she says this is the result of the conservativism that comes with war. And of course we also can see this in this country. War time is not necessarily a liberating time for women; it is sometimes a time of the hardening of the notion of who's a patriot. What's a patriotic, loyal woman like? She is a respectable woman. She is not an out spoken woman. She is not a woman who does "outrageous things." She supports the nation by supporting the standard view of what a respectable woman should be. Jaleel has actually helped found the Iraqi Women's League; she's a political activist now.

This is the last thing that I want to introduce today; if you take Iraqi women seriously one of the things you notice is that Iraqi politics today is much more complicated than any of us usually find out by listening to mainstream television or reading mainstream newspapers. Women have been organizing since two months after the occupation; there are now at least four different women's coalitions. They lobby the new ministries. They lobby anybody who's in power. They have even lobbied over here. And there are two main issues: number one, that the new Iraqi constitution not introduce Islamic family law. Remember Saddam Hussein's regime is very different from the conservative regime in Iran. The Saddam Hussein regime is a secular regime; it was not an Islamist regime, which is one of the reasons why bin Laden saw Saddam Hussein as his main enemy. Bin Laden wants a theocratic state; Saddam Hussein was 
dedicated to a secular state - a dictorial, oppressive secular state, but not an Islamist state. And what these women are now organizing around is to prevent the new powers in Iraq, those that have been appointed by the United States and those that are seen as cooperative with the American occupation, to prevent those new ministers from introducing Islamic family law into the new constitution. Only six out of 37 of the new ministers are women, so about 15 percent-which is lots better than the U.S. Congress at least, the U.S. Congress is 13 percent female in case you wondered who's developed. So Jaleel and the other women's groups are trying to prevent the introduction in Iraq of Islamic family law which would define women mainly in their relationship to their husbands and their fathers. What they are afraid of is that the U.S. occupation forces will be so keen on building alliances with any men who are willing to work with them that they will work with those male heads of political parties that will go along with the introduction of what's called Sharia law. This is about war; war involves organizing, war involves analysis, war involves strategizing. It's not just who's out on the street in a Humvee. It's not just who plants bombs on the side of the road. How many times have you read anything about women's organizing for the last year and a half?

The second issue that they are determined to pressure both the new Iraqi cabinet and the U.S. Ambassador, who still wields the final power because he's got all the money, is around women's security against physical violence. Women's security against physical violence must be taken seriously or how else can any women be active as a citizen in the supposedly new Iraqi government? In so far as a woman is afraid of being physically assaulted outside her home, she cannot act like a citizen. Any woman, in any society, who is subject to wife battery, for instance, cannot be a full citizen. Any woman who believes she is treated sexually as an object once she stands outside the safety of her home cannot be a full citizen. And that's what Jaleel and other Iraqi women who are very smart are organizing around. This changes our notion of what peace is. What is security? What are we going to use as measures of whether the war is going well? Are we going to listen to Jaleel? Thanks. [Audience applause] 
Professor Enloe is willing to entertain some questions. Any questions?

Or stories, I love stories!

Whenever accounts come out in the media about rapes, etcetera, there are those who say, here comes the liberal media again...

Most of us liberals think the New York Times is too conservative! But you're right.

So how can we get people to take this seriously?

I think this is a very good point. I think we have reached a moment in American political life, and this is about political life, where there is a lot of distrust of a lot of different media. I mean, I don't really trust Fox News. [Audience laughter] But now remember, for a lot of Americans that is where they are getting their news. How do I carry on a real conversation with somebody who finds Fox News the most accessible source of news? I think one of the things we can do, and this is the great advantage of the print media, is that you can decide what meaning you want to assign to a descriptive story. The print media is the place; I know it takes longer, but you can have a second mocha late at Starbucks as an excuse to read the paper. So, for instance, the story about Kim Gorski or the story about Nimo, those were written as pretty straight forward stories, there was no editorializing with them. I didn't know any of that, and reading it, I had to sort of think, what do I do with that? Some of the ordinary reporting, that isn't editorial page writing but is reporting, is sometimes very useful. I think for any of us to try and either on the web, or subscribing, or borrowing each others' newspapers to read the print media, and particularly descriptive stories, really helps. I think we all become more vulnerable and maybe even more cynical and suspicious if we think getting the news is listening to other people's analysis of the news. I know it's hard and I know we all have busy lives, but somehow we have to be the first source, not the third hand.

I'm going to hate this metaphor - do you ever do that, do you 
start out a metaphor and think, uh oh, where is this metaphor going? [Audience laugher] Well, I'll try it. We may not be the ones digging up the potato - that's the good journalist who's doing that work - and this is not a short story, this is not U.S.A Today; this is a story that goes from the front page to the inside. Sometimes it is a story that is on page 13, that isn't on the front page at all, but is a really good long story. At least we are then handling - this is where I am going to get in trouble with my metaphor-we are not the farmers digging up those potatoes, but at least we are handling the potatoes and we are going to decide what we are going to do with it. If we are only getting our sense of political life, no matter what our inclinations are, from the people who have already mashed them for us I think it really deskills us. Now I know it is hard to find the time, and I am lucky I'm a political scientist because I get to read the paper all the time, but if there's something to care about, if there is something that you know that you are complicit in, that you are responsible for, that you are going to have to vote on, then somehow we have got to get more of the gritty first hand account. A lot of these small women's groups in Iraq, at least four of them, now have their own websites and if you want, afterwards I can get you some of the websites. You can make up your own mind; they describe what they are doing, they describe what their goals are, they aren't telling you what to think, and you can actually see, oh my gosh, who knew that women were doing all this organizing in the midst of a war? So use the web as well and just go on to Iraqi women's groups on Google to find information first hand.

You've talked about women within the military being victims of violence and Iraqi women being victims at the hands of Iraqi men a little bit as well. What about Iraqi women being preyed upon by American military men?

This is very interesting. Joan Nagel and I share this terrible interest. The people who have made us smarter are Filipina feminists, Korean feminists, Puerto Rican feminists; they're the ones who have taught us to pay attention to what happens to women around U.S. military bases. No American women thought to look at what is going on around U.S. bases in the Pacific until Filipina feminists, 
as teachers, as journalists, and activists said, wake up! Do you have any idea what your military bases do? And of course most of us don't. Most of have no clue; it's not covered in the press because prostitution around military bases is normal. If something is normal, it is not news worthy, so you're not going to cover it. It took Filipina feminists and Korean feminists in the late 80s and early 90 s to wake up the rest of us. Every place that the U.S. military has an operation we've begun to always ask, what is the prostitution industry like? It would be a terrible thing to assume we know. Is there a prostitution industry? Who facilitates it? Who are the women drawn into prostitution? Often times around U.S. bases it's not willingly. Are there, as there are in Korea, bulletin boards in the U.S. military cafeterias that have pictures of Korean women? In Korea a woman has to get a license not to work as a prostitute-because prostitution is illegal in Korea-but as an entertainer. If she is found to have HIV is she given health treatment? No, no, her picture is turned upside down so that men won't go to her. That's a facilitation of the prostitution industry.

What seems to be happening in Iraq is that most U.S. military personnel there - this was also true in Saudi Arabia during the first Gulf War - are not allowed to mix with local Iraqis. It's a formal policy called non-fraternization. Non-fraternization is not a policy of the U.S. military in Korea or the Philippines. Watch the U.S. military not making the same decisions in these countries. Just in case any of us think this is natural or normal, no, no, it's about "policy assessment." In Saudi Arabia, Iraq, and in Kuwait, the policy of non-fraternization means that there is very little chance for any kind of interaction. Whether that has been one of the reasons that American women have been the subject of assaults, we don't know yet. From a piece in the Washington Post - and I'm going to give you this because this is really great journalism, this is no editorializing, this is absolutely straight - an article in the Washington Post on June $24^{\text {th }}, 2004$, by a Washington Post Journalist named Ariana Eunjung Cha, tells the story about one woman who is the daughter of a women who owns a small beauty salon. Her mother lost the beauty salon in the bombing and the daughter has decided to turn to prostitution. The story is not a scandalous story; it is a very 
down to earth story. This woman has decided that the only way she can feed her brother and her own kids is to go into prostitution. So there does seem to be a rise in prostitution because of war, and this happens in lots of countries because of poverty, although we don't have any evidence of it happening around U.S. components in Iraq. There is prostitution around U.S. military operations when they go on R\&R; so prostitution is part of the war in Iraq but it is not happening locally. It's definitely a question to keep asking.

What about prostitutes within the army-American women in the army who are prostituting themselves to earn extra income?

So maybe we need to ask the question really broadly. For any military, at any moment, in any place, how does prostitution work and what is the consequence? Things change. You study globalization. In the $60 \mathrm{~s}, 70 \mathrm{~s}, 80 \mathrm{~s}$, and early $90 \mathrm{~s}$ all the women that were in prostitution around U.S. bases in Korea were all themselves Korean women. But now, they are all Filipina, Russian, and Ukrainian. When you see the fall of the Berlin wall, think trafficking. That is, when you are studying prostitution around U.S. military bases always ask, why those women? Were those the women that were the same women ten years ago? If not, why? Part of the answer is globalization; when it takes place in Eastern Europe it caused the impoverization of women. Some of those women find themselves shipped to Korea.

Why not allow fraternization in Iraq? What differentiates Iraq from Korea?

We're trying to read the minds of Defense ministers now! [Audience laughter] This is exactly the skills we need; this is why we have to cross disciplinary boundaries and think, because watch what you've just done, which is just great. You've said, to make sense of U.S. foreign policy today we have to think about how senior people in the Defense Department think about women. That is serious. Here's the first time that the United States military, at the Defense Department level, decided to impose the policy of non-fraternization on U.S. military troops sent abroad is in Gulf War I and in Saudi Arabia. Here at least, we don't have the full 
story, but if you want to write an honors thesis, or a Master's or $\mathrm{PhD}$ thesis, we need it. But this is the little bread crumbs we've gotten so far. If you remember in 1990 when the Saddam Hussein army invaded Kuwait, next store was Saudi Arabia who was very nervous. You'll remember that in power in Saudi Arabia, and still in power in the same family was King Fahd who was the monarch. King Fahd was authoritarian and a conservative, but believe it or not, King Fahd has conservatives to his right. So whatever you think of King Fahd, there's somebody further to the right of King Fahd who is his competitor for power in Saudi Arabia. Saudi Arabian politics are very complicated, and those conservatives said, out loud, that if King Fahd invited the U.S. military to come into Saudi Arabia, to help protect Saudi Arabia from the advancing Iraqi forces, that they, the conservatives right of King Fahd, would claim that King Fahd was undermining the integrity of Saudi society and jeopardizing Saudi women to assault by American male soldiers. So King Fahd talked very seriously with the Defense Department negotiators and said, look, I want American forces to come in, but I can only have them come in if you will protect me from my even more conservative rivals, which means you've got to do everything to make sure that what you normally do in Thailand, what you normally do in the Philippines, what you normally do in Honduras, what you normally do in most of the other places that you go in to - that is, you allow for a highly sexualized "entertainment industry" to go up around the base-you cannot let that happen in Saudi Arabia. My whole regime will topple if I am seen as jeopardizing the integrity of the nation by jeopardizing the respectability of Saudi women. See how nation and women's respectability fill together? That was the first time the Defense Department made the decision that they would impose a non-fraternization policy.

Now keep watching here; so there were no entertainment districts around any of the U.S. encampments in Saudi Arabia. But when the U.S. forces returned to Yokosuka, the big base in Japan where a lot of the forces came from that were sent to the Gulf, they made a stop at Patong, Thailand, which is one of the most sexualized beach resorts in South East Asia. Now you just have to have a picture here. You're not in a motor boat and you think, oh, 
Patong, let's stop! [Audience laughter] You are an aircraft carrier fleet! How many memos do you think it takes to make the decision that a whole aircraft carrier fleet will stop for rest and recreation in Patong? And then we know from men who were on board that the thing that was done before the guys were allowed to go on shore is they were issued condoms. That's very different than sun block. [Audience laughter] That is, somebody thought that condoms are the thing they should issue.

I was there and Saudi Arabia was very different from other military bases.

That's right, and it really was diplomacy that made it different. Pay attention to women, and pay attention to how people at elite levels talk about women in order to create, and establish, and sustain alliances. Thank you very much folks.

\section{Notes}

${ }^{1}$ Kershaw, Sarah. 2003. "For Citizen Soldiers, an Unexpected Burden." New York Times September 15:A1.

${ }^{2}$ Tavernise, Sabrina. 2003. "Iraqi Women Wary of New Upheavals." New York Times May 5:A1. 